\title{
The Family Reunion as a turning point in T. S. Eliot's Verse Drama: Analysis and Suggestions for Translation ${ }^{1}$
}

\author{
Natalia Carbajosa Palmero
}

\begin{abstract}
Author:
Natalia Carbajosa Palmero

Universidad Politécnica de Cartagena, Spain natalia.carbajosa@gmail.com

https://orcid.org/0000-0003-1024-8408

Date of reception: 06/10/2020

Date of acceptance: $14 / 12 / 2020$

Citation:

Carbajosa Palmero, Natalia. 2022. "The Family Reunion as a turning point in T. S. Eliot's Verse Drama: Analysis and Suggestions for Translation." Alicante Journal of English Studies 36: 7-27. https://doi.org/10.14198/raei.2022.36.01

(C) 2022 Natalia Carbajosa Palmero

Licence: This work is licensed under a Creative Commons Attribution 4.0 International License (CC BY 4.0)
\end{abstract}

\begin{abstract}
:
T. S. Eliot wrote The Family Reunion (1939) while he composed the Four Quartets, twelve years after his conversion to Anglo-Catholicism in 1927. The play erects a bridge between the author's early stage productions (Sweeney Agonistes, The Rock and Murder in the Cathedral) and the later society plays (The Cocktail Party, The Confidential Clerk and The Elder Statesman). Moreover, in his 1951 essay "Poetry and Drama," Eliot delves into the strengths and weaknesses of The Family Reunion and links this play with his own experiments with a "conversational line" which introduces popular theatrical conventions wrapped in the patterns of poetry that may appeal to theatre-goers. This paper deals with Eliot's proposals for verse drama present in an incipient form in The Family Reunion, and explores the possible ways of translating these resources into Spanish. It focuses on Eliot's own explanations in "Poetry and Drama" about the way in which to adapt blank verse to the stage. Furthermore, this essay explores metrical concepts such as stress and caesura and applies them to wider aspects concerning dramatic patterns and inner/ outer voice in characters.
\end{abstract}

Keywords: The Family Reunion, Eliot's verse drama, theatre translation, blank verse, metrical concepts.

1 This study is part of the I+D research project funded by the Spanish Ministry of Science and Innovation T. S. Eliot's Drama from Spain: Translation, Critical Study, Performance (TEATREL-SP). 


\section{Introduction}

Compared to his poetry and essays, T. S. Eliot's verse drama has received so far scarce critical attention. In the following pages, I intend to contribute to a closer appreciation of this drama through one of his plays, The Family Reunion, which marks an unmistakable turning point in his dramatic career. I center my analysis on three aspects. I consider The Family Reunion a bridge between Eliot's earlier and later dramatic experiments, a fact which Eliot himself discusses in his essay "Poetry and Drama (1951);" I analyze the way in which Eliot's characters embody simultaneously real and transcendent voices, a technique which he developed in later plays; and, lastly, I assess the choices for a viable translation into Spanish of Eliot's verse form, especially the "conversational line" which he introduced in The Family Reunion. Eliot's poetic/dramatic register evolved in time: his plays gained in dramatic action and characterization through language, over other elements such as symbols, props or ritualistic staging.

In terms of methodological focus, this article follows Merino Álvarez's textual approach to drama translation (1994b, 127-138). From this standpoint, I deal with The Family Reunion as a whole unit of language-the micro level of drama translation-, from which I depart in order to analyze both the specific utterances within the whole-the macro level—as well as their relationship with former translations and other plays by the same author-the intersystemic level- Merino Álvarez's further differentiation among the three possibilities of drama translation as translation, version and/or adaptation, however, exceeds the limits of this work (1994a, 27).

Eliot's idea of the conversational line, towards which his practice as a playwright gravitates from The Family Reunion onwards, can be understood in terms of the descriptive drama translation concept known as "speakability" (Windle 2012, 115) which refers to the oral nature of the theatre play, that is, it places the emphasis on the naturalness of language in both the source and translated text. I follow Francis R. Jones's approach to poetry translation which encourages the use of "recreative translation," that is, a middle point between literal translation and the creation of a new poem. Within this recreative translation, I choose the analogical mode, defined by Jones as "a target form with a similar cultural function to the source form" $(2012,126)$. My proposals for the use of well-known Spanish meters for the translation of Eliot's conversational line are in line with Jones's approach. 


\section{Eliot as a Dramatist: The Creation of Verse Drama}

In addition to being a major poet and influential essayist who together with Pound shaped the modernist aesthetics in the 1930s, T. S. Eliot added a new dimension to his already prodigious oeuvre: that of a dramatist. Prior to The Rock (1934) and Murder in the Cathedral (1935), he had made an earlier attempt with the unfinished 1926 jazzy farce Sweeney Agonistes. Although considerably different, Eliot used Sweeney's plot, based on the classical myth of Orestes, in The Family Reunion (1939), a connection studied by Carol Smith (1967, 113-115). Eliot claimed that the evolution of a writer from poetry to drama is the correct trajectory for a writer. In his analysis of Shakespeare's plays as early as 1921 in "The Possibility of a Poetic Drama" (2014, 278-285), Eliot remarked that poetry had to be subservient to the purposes of dramatic action. Moreover, Eliot referred to the dialogic or dramatic qualities of his own poetry in which he identified three different voices depending on whether the poet is talking to himself, to a real or imaginary audience, or whether he uses an imaginary character as a mouthpiece addressing another imaginary character ("The Three Voices of Poetry," 1953).

Although Eliot's aims differed from those of the Spanish poets known as the 1927 Generation, his defense of verse drama is nevertheless comparable to their search for a "teatro de los poetas" ("drama of the poets") during the 1920s, a period also known as the Silver Age (Cuesta Guadaño 2017, 15-16; 42-46). In both cases, the poet-playwright aspired to do away with the prevailing realistic and naturalistic conventions and restore the stage to the musical cadences of poetry. Spanish authors such as Eduardo Marquina, Ramón María del ValleInclán, Francisco Villaespesa or Federico García Lorca embraced a mixture of folk, symbolist and surrealist techniques set in a remote, timeless or dreamlike verse. In contrast, from The Family Reunion onwards Eliot privileged contemporary, recognizable drawing-room settings and recommended "the capturing of the verse -its music- implicit in [colloquial] speech" "The Music of Poetry," 1942, 110). In this he explicitly admitted his debt to Yeats who, in Eliot's words, "solved his problem of speech in verse, and laid all his successors under obligation to him" ("Poetry and Drama," 1951, 595). At the same time, he praised the natural poetic speech and the rural setting present in Synge's Irish Literary Theatre, which, however, did not exactly serve his own purpose of creating a poetic conversational line: "The poetic drama in prose is more limited by poetic convention [...] as to what subject matter is poetic" (ibid., 594).

In order to fully understand Eliot's move towards theatre, it is necessary to refer to his conversion to Anglo-Catholicism in 1927. Thanks to the ritualistic, communal characteristics of theatre, Eliot considered it the ideal vehicle for the superimposition of the transcendent on ordinary reality. Thus, his characters 
act on two simultaneous planes and enact a "struggle of spiritual awakening" (Smith 2014, 253). His first two commissioned plays, The Rock and, above all, Murder in the Cathedral, anticipated this self-imposed task which he will develop in all of his plays. As a matter of fact, Eliot tried his hand at verse drama quite successfully in The Rock and Murder in the Cathedral, despite having admitted that he had arrived at a dead end. The historical, therefore remote plot of Murder in the Cathedral allowed for a classic mise-en-scène by means of a chorus and the solemnity of prophetic verse.

When Eliot analyzed Murder in the Cathedral, he acknowledged that he had managed to convey through verse drama the duality of the transcendent and the ordinary, but that this did not help him to continue doing so in dramas that were set in a contemporary period. Verse is naturally accepted in a historical and religiously themed work, but it does not function in the same way in a contemporary urban upper middle-class setting ("Poetry and Drama," 596-597). Anticipating criticism of future detractors of verse drama, Eliot contended that poetry is no more alien to real speech than elaborated prose. He concluded that poetry conveys moments of heightened consciousness much more intensely.

Yet the transition from Murder in the Cathedral to The Family Reunion was influenced by the simultaneous composition of the Four Quartets. Helen Gardner clearly relates Eliot's religious conversion with his later preference for the comedy, a genre which is more tolerant of man's sins than tragedy. Eliot's last three plays The Cocktail Party (1949), The Confidential Clerk (1953) and The Elder Statesman (1959), consolidate his search for a verse drama in the manner of conversational speech:

The earlier plays, like the earlier poetry, communicate a sense that life is agonizingly trivial and meaningless, unless some power from without breaks in to create a gleam of meaning (...) But in the course of Four Quartets a change of mood is clearly apparent. There is a progress towards acceptance of the conditions of life in this world, the kind of acceptance that underlies the comic writer's realism, sympathy, human compassion, and moral concern (Gardner 1966, 155).

After Murder in the Cathedral, Eliot abandoned historical drama and focused on his particular version of the "drawing-room comedy," one through which he could accommodate his Christian values in an upper middle-class contemporary milieu. The Family Reunion inaugurates this new line, even though it cannot be considered a comedy. 


\section{The Family Reunion: Preliminary Views}

Although The Family Reunion is still far from accepting "the conditions of life in this world," it nevertheless lays the foundations for the dramatic pattern-or Eliot's "double pattern" - which he will develop later in "Poetry and Drama." Eliot's "double pattern" consists in accommodating a varied confluence of opposites: conscious/unconscious, verse rhythm/conversational speech rhythm, the quotidian/the transcendent, and popular theatrical conventions/highbrow literature. All these opposites are encompassed by a larger divine design, that confers on the play its final purpose, duly summarized by Agatha in her role of contemporary sibyl: "So the knot be unknotted / The crossed be uncrossed..." (TFR, 350). Other signs similar to Agatha's message can be traced in the seasonal rebirth - the spring that struggles to arrive-and even in the division of the play into only two acts: a first, in which the protagonist's ordeal is exposed, and a second in which the intercession of two crucial characters, Dr. Warburton and Agatha, propitiates the denouement.

In The Family Reunion, Eliot resorts again to the mythical method, which sets up an onstage parallelism between antiquity and contemporaneity. Thus, Aeschylus's The Eumenides serves as a reference point to a modern tale of sin and expiation (Tanner 1970, 127-128). The apparition of the Eumenides, or Furies, disturbs the placid setting of a twentieth-century country manor. In the play, dialogue and casual exchanges are interrupted by Agatha, and by the rest of Amy's relatives who impersonate a Greek chorus. At certain moments, the characters speak "beyond character", and their irrelevant, everyday remarks are invested with transcendent wisdom.

All these obvious strategies are more subtly blended in Eliot's further plays. Hence, from The Cocktail Party onwards, the strategy of the double nature of the action will rely on the shifts and changes in verse rhythm and cadence, that is, on the very dynamics of verse drama, rather than on any extralinguistic resources. Eliot reflections document this evolution:

These passages [Agatha's and the chorus's] are in a sense "beyond character," the speakers have to be presented as falling into a kind of trance-like state in order to speak them. But they are so remote from the necessity of the action that they are hardly more than passages of poetry ("Poetry and Drama," 599; my italics).

Eliot's ultimate goal was to take verse drama to average theatre-goers. He did not want "to transport the audience into some imaginary world totally unlike its own," to "an unreal world in which poetry is tolerated" ("Poetry and Drama," 
596). By focusing on language instead of on staging techniques, by eliminating lyric passages with no real connection to dramatic action, Eliot attempted to introduce major innovations in contemporary dramatic art. A closer look at some key passages in The Family Reunion allows us to assess the scope of Eliot's endeavor and realize the path-breaking nature of this play.

\section{A Metrical Analysis of The Family Reunion}

Eliot defines his attempt to use a dramatic verse form that sounds like conversation through the technicalities of metrics:

A line of varying length and a varying number of syllables, with a caesura and three stresses. The caesura and the stresses may come at different places, almost anywhere in the line; the stresses may be close together or well separated by light syllables; the only rule being that there must be one stress on one side of the caesura and two on the other ("Poetry and Drama," 599).

If we try to apply Eliot's general rule to the opening line of The Family Reunion, this may be a plausible reading with a possible set of accents:

AMY. Not yét! I will ríng for you. // It is stíll quite light.

(TFR, 285)

Amy (Lady Monchensey), the owner of the house, asks the maid not to draw the curtains yet. She is introduced as a strong character who, despite her many disillusions in life, still tries to force her will upon others. Because of the length of the line, the first two stresses may fall before the caesura. The second part of the line does not contain an order but a remark. Thus, the stress may fall on two of the three contiguous monosyllabic words ("still", "light"). Their similar semantic load makes the choice difficult: time and light in contrast with darkness are central to the meaning of the play, and Eliot always recommended stressing semantically loaded words. However, the earlier mention of "still" sets up a contrast with "yet" at the beginning of the same line.

Critics have often contested Eliot's three-stress verse pattern, arguing that in fact he uses a four-stress pattern. Relying on testimonies from Eliot's close collaborator Martin Browne, Marjorie Lightfoot concludes that the predominant pattern of expectation in the play as well as in this passage is the 4-stress line (1964, 262-263). Patrick Dudgeon also identifies four stresses instead of three in the same opening lines $(1953,36)$; while Alfredo Olivera, the translator of three of Eliot's plays into Spanish, reaches a similar conclusion in his 
introductions to The Cocktail Party (Cocktail Party, 1950) and The Confidential Clerk (Su hombre de confianza, 1959).

Critics and translators agree, however, on the fact that Eliot consciously avoids the overuse of the iambic pentameter, which had been the most frequently used form in blank verse until the twentieth century. ${ }^{2}$ In addition, these critics highlight the importance of Eliot's search for a system of accents flexible enough to reproduce the cadence of conversation in a 3- or 4-stress pattern. In Lightfoot's words:

The 4-stress line [3-stress line for Eliot] appears in The Rock and Murder in the Cathedral, as well as in "Four Quartets," together with many other verse forms. But it is the basic line in The Family Reunion, The Cocktail Party, The Confidential Clerk, and The Elder Statesman (...) The dramatist experimented with this line, from play to play, through changes of diction, style, syntax, and characterization, in his growing desire to find a verse form which would contain the rhythm of contemporary speech, but would not call attention to itself as verse as it does in Sweeney Agonistes (1968, 189).

Moreover, critics have consistently remarked that Eliot resorts to verse form as a characterization strategy. Concerning The Family Reunion, Dudgeon recalls Browne's remarks about the way in which characters are distinguished by meter and stress: thus, Ivy speaks in dactylic feet (a stressed syllable, followed by two unstressed syllables), monosyllabic strong strikes are employed in the case of Violet, and relaxed, smooth tones for Charles $(1953,37)$. Likewise, D. E. Jones analyzes a conversation of these characters in Scene I from Part I based on "the degree of control that the verse gives over characterization and dramatic tension" (1963, 119). Taking this technique to the extreme, Wyman contends that, in Eliot's plays, "the words are what happens" $(1991,44)$.

This conception of the play privileging dialogue over action, often used as a critique of the lack of action, seems adequate for the overwhelming frequency with which the characters use verbs and expressions related to language itself: explain, think, express, understand, see. Harry's chauffeur, Downing, seems an especially eloquent case. As for Harry, the protagonist, he repeats several times that he would need to command another language to be able to explain his inner anguish. Eliot himself argues in his 1944 Introduction to Bethell's Shakespeare and the Popular Dramatic Tradition that the characters in verse drama should

2 "[F] or I was persuaded that the primary failure of nineteenth-century poets when they wrote for the theatre (...) was their limitation to a strict blank verse which, after extensive use for non-dramatic poetry, had lost the flexibility which blank verse must have if it is to give the effect of conversation" ("Poetry and Drama," 596).

Alicante Journal of English Studies, Issue 36, 2022, pages 7-27 
"disclose (not necessarily be aware of) a deeper reality than that of the plane of most of our conscious living" (504). This disclosure of a deeper reality through verse is what allows dramatic action to unfold, which I am going to analyze in the following examples.

By means of his own analysis, Eliot offers a deeper understanding of why verse form in The Family Reunion sets the standards for his future dramatic career. The three or four stress conversational line coexists here with other identifiable, highly stylized verse forms through which dramatic action is interrupted. On these occasions, characters speak as if in a trance, unconscious of their momentary inclusion in a larger-than-life design. These interruptions often confer a fleeting perception that they contain something strange in themselves ("What have we been saying?"). As early as Scene I, the Sibyl-like voice of Agatha interrupts the ongoing conversation:

GERALD. That will be a little difficult. /

VIOLET. Nonsense, Gerald!

You must see for yourself it's the only thing to do.

AGATHA. Thus with most careful devotion

Thus with precise attention

To detail, interfering preparation

Of that which is already prepared

Men tighten the know of their confusion

Into perfect misunderstanding,

Reflecting a pocket-torch of observation

Upon each other's opacity

Neglecting all the admonitions

From the world around the corner

The wind's talk in the dry holly-tree

The inclination of the moon

The attraction of the dark passage

The paw under the door.

(TFR, 290)

No transition is marked here from Gerald's and Violet's conversational line to Agatha's shorter, rhymed lines. Agatha's verse changes the mood: suddenly there is rhyme, and the theme of the previous lines is changed. Furthermore, the choice of matter-of-fact language gives way to the symbolic inclusion of remote elements such as "the dry holly-tree", "the moon", "the dark passage", "the paw." This elusive, oracle-like blending of imagery, metrics and language, so reminiscent of Eliot's poetry in general and of Four Quartets in particular, will be completely eliminated in the later plays. 
Agatha's citation above does not advance Eliot's search for a conversational line embedded in dramatic action and characterization. In contrast, in The Family Reunion the characters express themselves in the rhythm of common speech, putting into words a pedestrian worldview; it is where Eliot most successfully provides factual information for the plot while he subtly discloses a deeper reality. This is where the conversational line allows him to further explore its possibilities, leaving all unreal speech elements behind. I will try to prove this hypothesis using the text itself. In order to do this, I will return again to the play's opening lines:

AMY. Not yet! I will ring for you. It is still quite light.

I have nothing to do but watch the days draw out,

Now that I sit in the house from October to June,

And the swallow comes too soon and the spring will be over

And the cuckoo will be gone before I am out again.

O Sun, that was once so warm, O Light that was taken for granted

And the night unfeared and the day expected

And clocks could be trusted, tomorrow assured

And time would not stop in the dark!

Put on the lights. But leave the curtain undrawn.

Make up the fire. Will the spring never come? I am cold.

AGATHA. Wishwood was always a cold place, Amy.

(TFR, 285)

The mood is set in these first apparently simple informative lines invested with solemnity, as in Murder in the Cathedral. They seem dramatic soliloquies predicated on symbolic opposites (light and dark, spring and winter) that add to the resonance of the place itself, Wishwood. Amy's discourse resembles Burnt Norton's philosophical reflection "time present and time past." This tone is more clearly evoked in Ivy's reply to Amy:

IVY. I have always told Amy she should go south in the winter. Were I in Amy's position, I would go south in the winter.

I would follow the sun, not wait for the sun to come here.

I would go south in the winter, if I could afford it,

Not freeze, as I do, in Bayswater, by a gas-fire counting shillings.

Ivy's idle chatter, trivial as it sounds and resentful of her lack of wealth, contains an insistent repetition, an echo, of a crucial verse in The Waste Land: "I read, much of the night, and go south in the winter" (TWL, 61). Eliot's critique of the wastelanders' escapist evasion of winter and darkness in an attempt to avoid the 
natural cycle is repeated here (Patea 2011, 97). At the same time, "I would go south in the winter" sounds like a perfectly banal comment both in Ivy's as well as in Countess Marie Larisch's confession in The Waste Land. ${ }^{3}$ At this point the double pattern is successfully achieved not only at a denotative level of the words used but also on a connotative plane.

Consequently, the main challenge of any translation into Spanish must reproduce Eliot's particular strategy. It must convey the mere facts of the situation and the conventionality of the characters, and it should simultaneously open up spaces, like a sounding board for the "beyond character" dimension of the protagonists. Moreover, the staging of the scene must show the proper correspondence between meaning and stress transmitted by the metrics of the conversational line and regardless of the spectators' perception of a prose or verse dialogue. As the Spanish poet Claudio Rodríguez aptly remarked, referring to Rimbaud's poetic rhythm: "La palabra significa en la medida que suena" (2004: 91), that is, "the word is invested with meaning as long as it sounds." Rodríguez's statement may well be applied to Eliot's innovations in verse form.

\section{Translating The Family Reunion into Spanish}

Before approaching the issue of translation, I would like to consider he nature and tradition of Spanish verse. At the time when Eliot attempted to transform English blank verse into his particular version of the conversational line, Spanish and Spanish-American poets were also experimenting with a conversational line in varied ways. Inspired by Walt Whitman's verse, Jorge Luis Borges, Juan Ramón Jiménez, Pablo Neruda, Vicente Aleixandre, Vicente Huidobro or Carlos Bousoño began to incorporate English verse to a poetic tradition which, until then, had almost exclusively relied on French literature and in particular, the Symbolist movement. From the first decades of the twentieth century onwards, Spanish-American poets adopted Anglo-American free verse and wrote poems of varied strophic lines and syllables. In this respect, Eliot's innovations are similar to Spanish verse experimentalism: the blurring of barriers between poetry and prose, and the introduction of specific stress patterns that maintain this inbetween verse-prose cadence (Utrera 2003, 303-333).

As regards the transgression of barriers, Borges emphasized that free verse is indebted to an archaic world without limits between verse and prose (Ibid., 308), while Jiménez related it to "the naturalness of the prose and to the principle

3 Countess Marie Larisch was the niece of the last empress of the Austro-Hungarian Empire. Eliot's verse evokes her own words in her memoirs, My Past (1913), as well as private conversations he had with her. 
of the genuine expression of subjectivity and personal rhythm" ${ }^{4}$ (Ibid., 320). Concerning stress patterns, Bousoño concluded in his analysis of Aleixandre's use of free verse that:

The possible irregularities within the general predominance of the hendecasyllable rhythm can be perfectly assumed within the poetic structure, since the dislocated rhythmic units are absorbed by the majority rhythmic mass of the poem (Utrera, 323). ${ }^{5}$

Bousoño's statement confirms that the main rhythmic pattern of the new innovations within Spanish verse are those of the hendecasyllable, which arguably expresses the length of an average utterance. Contemporary critics and Bousoño's poet-fellows argued that this is, in effect, the verse form that prevails over the irregular rhythmic cadence of free verse.

The translation of English poetry into Spanish constitutes a serious challenge, since English metrics like Latin and Greek are measured by units of different length called feet, while Spanish verse is based on syllabic stress and all syllables have the same length. Olivera's own evolution in his translations of Eliot's theatre clearly shows that there can be more than one possible approach to his drama. For The Cocktail Party, Olivera prefers the Spanish fourteen-syllable line, also called alexandrine (alejandrino), as the prevailing rhythm instead of the hendecasyllable (Olivera 1950, 9-16). His choice seems to be in consonance with Eliot's own indications about the use of caesura in his conversational line, since the alexandrine specifically consists of two seven-syllable parts divided by a caesura. Moreover, it gives more scope to the translator for the introduction of Spanish words which are usually longer than English words.

Both the hendecasyllable and the alexandrine are verse forms with a long tradition in Spanish poetry. The hendecasyllable is the meter used in Spanish sonnets. Conversely, translators from English into Spanish usually opt for the alexandrine when they translate English sonnets, precisely because of the length variation between the two languages. That is the reason why Olivera's choice of the alexandrine for Eliot's conversational line seems in principle adequate, even if the hendecasyllable prevails in Spanish free verse. This is how Olivera

4 "a la naturalidad de la prosa y al principio de expresión auténtica de la subjetividad y el ritmo personal."

5 "Las posibles irregularidades dentro del general predominio del ritmo endecasilábico se asumirían perfectamente dentro de la estructura poemática, ya que las unidades rítmicas dislocadas quedan absorbidas por la masa rítmica mayoritaria del poema." Unless otherwise indicated, all the translations from Spanish poets included in this article have been translated by its author. 
translates the opening lines of The Cocktail Party, translated as Cocktail Party. I am marking the rhythmic accents of the Spanish syllables in bold type, so as to differentiate them from the diacritical sign that indicates word stress. In contrast, the underlined syllables show possible alternative accents:

ALEX You've míssed the póint // complétely, Julia:

There wére no tigers. // Thát was the póint.

ALEX. Julia, no has comprendido // la gracia de este cuento.

No hubo tales tigres. // En eso está la gracia.

$(C P, 19)$

Olivera renders these lines in two perfect alexandrines. In the second line, he reproduces the same accentual pattern as the original (were/hubo; that/eso), whereas in the first one he has to make some changes. ${ }^{6}$ He moves "the point" ("la gracia') to the second part of the line and lets the stress fall on the first syllable of the verse ("Julia"). With this decision, Olivera privileges the alexandrine above other metrical forms.

A recent alternative to Olivera's metrical choice is provided by the Eliot scholar and translator Dídac Llorens-Cubedo in a still unpublished translation of the same play. Llorens-Cubedo renders these two lines in nine-syllable and twelve-syllable forms, thus approximating his choice to the hendecasyllable instead of the alexandrine:

No has entendido // nada, Julia:

No había tigres. // Ahí está la clave.

Commenting on his 1959 translation of The Confidential Clerk (Su hombre de confianza), Olivera admits some shortcomings in his previous metrical choice and attempts a different solution: he adopts a complex system that relies more on a particular use of the classic feet than on any available syllabic Spanish lines. I must admit that I find his technical explanations somewhat confusing, but his intentions are unequivocal:

6 There is an implicit fundamental difference between the "accentual pattern" of languages whose poetic rhythm is based on feet (English) and the prevailing "rhythmic accents" in Spanish long verse lines. In the latter case, stress is provided by the verse form itself and does not always coincide with the stress of each word (see Torre, 1999: 32). 
The abundance of dactyls will confer the desired agility and lightness to the scene. In turn, the absence of rhyme and of any regular syllabic meter (elements are also not found in the original) will eliminate that drum beat that the ear of an average audience is used to calling verse, so that many will believe that they are listening to prose, like their colleagues in an English audience" (1959:19). ${ }^{7}$

It is true that in Spanish the continuous use of the alexandrine, even if unrhymed, will always sound like poetry. Therefore, this verse form is far from being a Spanish desirable equivalent to Eliot's conversational line. At the same time, Spanish free verse shows a clear tendency to adopt the stress patterns of the hendecasyllable. This tendency is reinforced when the hendecasyllable alternates with the alexandrine, especially when translating from English, a language in which, unlike Spanish, monosyllables abound to a high degree. Consequently, a combination of these two verse forms may well serve the purpose of translating Eliot's conversational line into Spanish. This affects lines that naturally fluctuate between nine and twelve syllables close to the hendecasyllable -Llorens-Cubedo's choice- and longer lines similar to the alexandrine that usually have between thirteen and sixteen, or even eighteen syllables. Such a translation renders the smooth flow of a prose/verse rhythm, and is an adequate equivalent to Eliot's conversational line. As for the caesura, it continues balancing accents along the line.

It is a pity that the 1953 translation of The Family Reunion by novelist Rosa Chacel, Reunión de familia, should not include any explanations about her own decisions. ${ }^{8}$ This is how Chacel translates the opening lines:

7 La abundancia de dáctilos dará al diálogo una ligereza y levedad muy deseable en la escena, y la ausencia de rima y de toda métrica regular silábica (elementos que, por otra parte, tampoco se hallan en el original) eliminará ese tambor que el oído de un público medio está acostumbrado a llamar verso, de modo que muchos creerán estar oyendo prosa, como sus colegas del auditorio inglés.

8 There is also a typed 1956 version of Reunión de familia, of which a single copy is kept at the Archivo General de la Administración, in Alcalá de Henares, together with the attached censorship file 101-56 (05-04-1956). On the cover page can be read: "Traducción ('Translation'): Elisa Fernández-Cancela; Revisión poética ('Poetic revision'): Carmen Conde". Using this copy, the play was staged that year in Madrid by the Dido, Pequeño Teatro Company. The reviews referred to the translator as "Elizabeth Gate." Carmen Conde argued that she used free verse ('versos blancos') when adapting Eliot's conversational line (Ya, 19/06/1956). However, Rosa Chacel's translation, published by Emecé in Buenos Aires, and the manuscript by Gate/Conde are the same text. Admitting that there is an unresolved mystery, we provisionally hold to Chacel's authorship, since her version appeared three years before the other one. 
AMY. Todavía no; es de día aún. // Yo la llamaré.

No me queda otra cosa que hacer // sino ver cómo crecen los días.

Ahora me quedo en casa // desde octubre hasta junio.

Y la golondrina llega muy temprana // y la primavera ya se habrá acabado

Y se habrá ido el cuclillo // para cuando yo vuelva a salir.

$(R F, 46)$

In this passage we can see the tendency towards the alexandrine in lines one, three and six, each line has sixteen, fifteen and seventeen syllables, respectively. The other two lines are twenty and twenty-four syllables long. Chacel tries to maintain the caesura and does not seem to be so concerned with length. Her translation overcomes prose/verse boundaries. In my own translation, I try to reduce the length of longer lines so as to let the rhythmic accent fall more clearly on meaningful words, while I avoid too conspicuous stress patterns of hendecasyllables and alexandrines: ${ }^{9}$

AMY. iTodavía no! Ya la llamaré. // Aún hay claridad.

No tengo nada que hacer // salvo ver pasar los días,

Ahora que estoy en casa // desde octubre hasta junio,

Y se adelanta la golondrina // y se irá la primavera

Y el cuco se habrá ido // cuando yo vuelva a salir.

In this case, the lines count seventeen, fifteen, fifteen, eighteen and fifteen syllables, respectively. I have maintained a uniform syllable pattern so as to create a similar mood as in the original, halfway between the implicit and the explicit, the factual and the lyrically elusive. "Claridad" ('clarity') is an appropriate term for the "light" symbolism recurrent in the play and, as such, it needs to be stressed. Both my translation and Chacel's naturally reproduce the original predominance of other crucial words like 'ahora' and 'casa' ("now" and "home") in line 3. Yet, in order to shorten the fourth line, I have changed Eliot's noun and verb phrase order, which Chacel maintains. However, the final position of two four-syllable nouns of equal stress on the second-to-last syllable ('golondrina' and "primavera', that is, "swallow" and "spring") maintains the stressed accent of the original. All this requires a translation technique that must allow for intuitive changes of meter, accent, word sound and position in the line while

9 A way of writing poetry that does not "sound" so conspicuously like poetry is favored in Spanish by asymmetric stress ('acentuación asimétrica') which consists of accentual choice that does not let the syllabic stress be uniformly identified with the rhythmic one. 
always trying to reproduce conversational speech. As for the syntactic parallelism between the two halves of the line, emphasized in Eliot's original through the lines that repeatedly begin with "And", both Chacel's and my own translation are faithful to the original patterns.

The correct translation would be a medley of several verse forms gravitating towards the hendecasyllable or the alexandrine. Amy's opening lines tend towards the alexandrine, a solemn verse form per se, very adequate for a situation in which the protagonist wants to convey the impression of being in absolute control of the situation. Later in the play (Part II, Scene III), when she gradually discloses her more uninhibited self, she transmits anger and drops social etiquette, her speech becomes emotional, rich in monosyllables, interrogations and exclamations. In this example, in which Amy addresses Agatha once intentions have been revealed, the verse approaches the hendecasyllable:

... I would have sons, // if I could not have a husband:

Then I let him go. // I abased myself.

Did I show any weakness, // any self-pity?

I forced myself // to the purposes of Wishwood;

I even asked you back, for visits, // after he was gone,

So that there might not be // ugly rumours.

You thought // I did not know!

This is how Chacel translates this passage:

Ya que marido no tenía, tendría hijos.

Entonces le dejé que se marchara. Me rebajé.

¿Es que mostré debilidad, tuve alguna piedad para conmigo misma?

Me sacrifiqué en aras de Wishwood;

Llegué a invitarte a visitarme después que él se marchó,

Para evitar rumores desagradables.

iCreíste que no lo sabía!

$(R F, 132)$

In Chacel's version, only lines 4, 6 and 7 come close to the hendecasyllable. The conversational tone is maintained and it does not depart too much from the original syntax and word order, except for the first line. My own version is:

Tendría hijos, // ya que no marido:

Luego lo dejé marchar. // Me rebajé. 
¿Mostré autocompasión, // debilidad?

Me entregué a lo que Wishwood // requería;

Hasta te volví a invitar // cuando él se fue,

A fin de acallar // molestos rumores.

¡Creías que no lo sabía!

In this provisional translation, all the lines resemble the hendecasyllable. Line 4, for example, is a perfect hendecasyllable. Moreover, it reproduces the traditional rhythmic accents of the type called endecasílabo melódico (melodious hendecasyllable), with stresses on the third and sixth syllables, besides the required stress on the tenth syllable ("Me en/ tre/ gue a/ lo/ que/ Wish/ wood/ re/ que/ rí/a"). The remaining lines include different variations of stresses that avoid a highly marked poetic rhythm indebted to verse, although on the whole, prose and verse have the same importance.

The line choice depicts Amy's psychological process, inasmuch as it combines alexandrines and hendecasyllables. Such an evolution can be noticed when we compare Amy's introductory exclamation ("iTodavía no! Ya la llamaré. Aún hay claridad") with her second outburst ("Tendría hijos, ya que no marido"). The former presents an ordered parallel structure before and after the caesura with a constant alexandrine pattern, while the latter shows a more fluent structure, because of its shifting length and caesura. As regards syntax, the lines that Amy utters towards the end of the play favor enjambment, a characteristic of key characters like Agatha and Dr. Warburton who influence Harry's development. The following passage confirms Amy's final understanding of life:

At my age, I only just begin // to apprehend the truth

About things too late to mend: // and that is to be old.

Nevertheless, I am glad // if I can come to know them.

(FR, 345)

For the translation of this passage, I propose a blending of the alexandrine and the hendecasyllable - the first lines have 16 and 17 syllables while the third has 12-as a rhythmic index of Amy's coming to terms with her inner dilemma:

A mi edad, empiezo apenas // a discernir la verdad

Sobre cosas que ya no puedo enmendar: // eso es ser vieja.

Sin embargo, me alegraré // de entenderlas. 


\section{Further Considerations}

The evolution of Amy as a character who also undergoes a partial process of enlightenment or dramatic anagnorisis is relevant when she resorts to the conversational line. In this she differs from characters like Harry, Agatha or Mary, who switch to verse forms which Eliot explicitly identified as "beyond character" strategies. In this sense, Amy anticipates the development of characters such as Edward in The Cocktail Party, Colby in The Confidential Clerk or Lord Claverton in The Elder Statesman who confront their selfishness, true vocation or public image, respectively. These three figures live moments of revelation similar to Amy's, but their speech does not abandon the usual verse pattern. Hence:

Edward in The Cocktail Party:

The self that wills - he is a feeble creature;

He has to come to terms in the end

With the obstinate, the tougher self;

$(C P, 381)$

Colby in The Confidential Clerk:

The person I used to be, returns to take possession:

(TCC, 463)

And Lord Claverton in The Elder Statesman:

I've been freed from the self that pretends to be someone.

(TES, 582)

Such crucial moments are naturally blended in the flow of the text with no warning. These moments of awareness resemble the meditations of the Four Quartets, as well as the inner, monologic voices of Eliot's early poems. They take place among trivial scenes and futile dialogues without any choruses or modifications of the conversational line. Only Monica and Charles's love lyrics in The Elder Statesman are the exception to the rule.

In play after play, Eliot experiments with verse forms in order to insert these crucial moments of awareness into the natural course of events, a strategy with which he sets up a correspondence between words and action. Despite its length, I quote Smith's eloquent analysis:

In his last comedies, Eliot worked to eliminate the poetic effects he felt had drawn attention to verse in The Family Reunion—runic passages, lyric duets like 
those between Harry and Mary, and the choruses. In The Cocktail Party, to avoid the musical effects of spoken verse, he turned instead to other "poetic" effects such as extended images, repetition of phrases, and structural repetitions of all kinds available in the patterning of comedy. In The Confidential Clerk the verse is further 'thinned', the dialogue less stylized and the comic effects limited to the traditional comic situations of misplaced children and divine intervention to solve issues of identity. In The Elder Statesman, while the verse form hast been technically preserved, the tone is more sombre, and the lyric passages are saved for the young lovers, to emphasize the theme of human love as an instrument of purgation and salvation $(2014,261)$.

The relevant feature is that dramatic characterization of this kind is honed upon a verse form not intended to be perceived as such and which is only very subtly used as an indicator of a deeper reality. Moreover, it is not by chance that Eliot declares in "Poetry and Drama": "My sympathies now have come to be all with the mother, who seems to me, except perhaps for the chauffeur, the only complete human being in the play" (601). Unlike other characters, such as Agatha, Amy's psychological development is rendered through the parameters of the conversational line which is crucial for character development as well as apt for plot progression. Eliot conceives dramatic action as the accrued revelation of deeper meanings through surface speech, since in Wyman's phrase "the words are what happens."

The Family Reunion marks a turning point in Eliot's dramatic career. It inaugurates new strategies. Chronological sources besides the author's own testimony in "Poetry and Drama" confirm this assumption. As Lightfoot argues:

In "The Need for Poetic Drama," broadcast in 1936, the poet stated that in verse drama versification should be emphasized rather than minimized (...) In "Religious Drama: Medieval and Modern," 1937, Eliot expressed both a desire to see religious principles embodied in serious drama, and an awareness that verse drama must compete with the popular theatre on its own grounds. This was the turning point. $(1968,191)$.

All of this evidences a well-thought decision of ample scope, which involves not only theatrical praxis but also a Weltanschauung expressed through an experimental verse form.

\section{Conclusion}

For the purposes of translation into Spanish, the translator must pay close attention to Eliot's use of the conversational line when his dramatic characters 
experience heightened moments of consciousness. Those almost unnoticeable signs of speaking "beyond character" in the course of a casual conversation need to be carefully identified in translation so as to avoid an excess of formality. The translator needs to render the Eliotian spirit of simultaneous dramatic patterns, the intersection of the real and the transcendent.

In its premiere in Madrid in 1956, Reunión de familia received the same mixed appreciation as in London in 1939. Overall, dialogues were praised for their brilliance while lack of action was signaled as the main flaw. One review stated that "the lyric choruses are splendid. The dialogue is slow, obscure and uninteresting, since it gravitates towards an anti-dialogue" (Estafeta literaria Madrid, 23/06/1956).10

By trying his hand at verse drama once he achieved fame as a poet, Eliot's craft was put to the test at home and abroad. Such circumstance did not deter him from exploring new poetic and dramatic paths ultimately conducive to the use of new verse forms which had never before been applied to drawingroom drama. Whether Eliot's achievements onstage are considered satisfactory or not-a controversial issue to this day-, the analysis of his dramatic praxis, together with his own theoretical speculations on this issue, enhance his oeuvre. I hope this article provides some suggestions to those who will take up the challenge of translating Eliot's theatre into Spanish.

\section{Works Cited}

"7 días." Estafeta literaria de Madrid, 23/06/1956. Archivo Carmen Conde, Cartagena. "Antecrítica de Reunión de familia." Ya, 19/06/1956. Archivo Carmen Conde, Cartagena.

Beenler, Michael. 1998. "Metaphysics and Dramatic Praxis: Eliot on the Rhetoric of Drama". CEA Critic 51 (1): 103-113.

Chinitz, David. E. 2002. T. S. Eliot and the Cultural Divide. Chicago: University of Chicago Press.

—., ed. 2014. in A Companion to T. S. Eliot. Chichester: Blackwell.

— and Ronald Suchard, eds. 2017. The Complete Prose of T. S. Eliot: The Critical Edition, Vol. 6: The War Years, 1940-1946. Baltimore. MA: Johns Hopkins University Press.

CUDA, Anthony. 2016. "A Precise Way of Thinking and Feeling: Eliot and Verse Drama". In Harding 2016, 116-130. https://doi.org/10.1017/9781139583411.010

10 "los recitados corales, estrictamente líricos, son espléndidos. El diálogo, lento, oscuro y poco interesante, por orientarse hacia un anti-diálogo." 
— and Ronald Schuchard, eds. 2014. The Complete Prose of T. S. Eliot: The Critical Edition, Vol. 2: The Perfect Critic, 1919-1926. Baltimore. MA: Johns Hopkins University Press.

Cuesta Guadaño, Javier. 2017. "El teatro de los poetas: Formas del drama simbolista en España (1890-1920)". Madrid: CSIC.

DudGEOn, Patrick O. 1953. "Introducción a Reunión de familia." Buenos Aires: Emecé Editores.

Elıot, T. S. 2004. The Family Reunion (in The Complete Poems E Plays), 283-350. Faber and Faber.

-. 2004. The Waste Land (in The Complete Poems E Plays), 59-80. Faber and Faber.

-. 2004. The Cocktail Party, (in The Complete Poems E Plays), 351-442. Faber and Faber.

-. 2004. The Confidential Clerk, (in The Complete Poems \& Plays), 443-520. Faber and Faber.443-520.

-. 2004. The Elder Statesman, (in The Complete Poems \& Plays), 521-584. Faber and Faber.

—. 1953. Reunión de familia, trad. de Rosa Chacel. Buenos Aires: Emecé Editores.

—. 2018 (1951). "Poetry and Drama", in Javadi and Schuchard 2018, 589-610.

—. 2018 (1953). "The Three Voices of Poetry". In Javadi and Schuchard 2018, 813833.

-. 2018 (1953). "The Music of Poetry". In Javadi and Schuchard 2018, 310-325.

—. 2017 (1944). "Introduction" to Shakespeare and the Popular Dramatic Tradition, in Chinitz and Schuchard 2017, 7-9.

—. 2014 (1920). "The Possibility of a Poetic Drama", in Cuda and Schuchard 2014, 278-285.

Gardner, Helen. 1966. "The Comedies of T. S. Eliot". The Sewanee Review 74 (1): 153-175.

Harding, Jason, ed. 2016. The New Cambridge Companion to T. S. Eliot. Cambridge: Cambridge UP. https://doi.org/10.1017/9781139583411

Javadi, Iman and Ronald Schuchard, eds. 2018. The Complete Prose of T. S. Eliot:

The Critical Edition, Vol. 7: A European Society, 1947-1953. Baltimore. MA: Johns Hopkins University Press.

Jones, D. E. 1963. The Plays of T. S. Eliot. London: RKP.

Jones, Francis R. 2012. "The Translation of Poetry". In Malmkjaer and Windle 2012 123-131.

Lightfoot, Marjorie. "Purgatory and The Family Reunion: In Pursuit of Prosodic Description”. Modern Drama 7.3 (1964), 256-266. https://doi.org/10.3138/ md.7.3.256

—. "Charting Eliot's Course in Drama". Educational Theatre Journal 20.2 (1968), 186-197. https://doi.org/10.2307/3204902 
Malmkjaer, Kirsten and Kevin Windle, eds. 2012. The Oxford Handbook of Translation Studies (Online Publication Date). Oxford: Oxford UP. https://doi.org/10.1093/ oxfordhb/9780199239306.001.0001

Merino ÁlvAREZ, Raquel. 1994a. Traducción, tradición y manipulación: Teatro inglés en España 1950-1990. Universidad de León/Universidad del País Vasco.

—. 1994b. "A Framework for the Description of Drama Translations." Revista canaria de estudios ingleses 29: 127-140.

Olivera, Miguel Alfredo. 1950. "Introducción a Cocktail Party”. Buenos Aires: Emecé Editores.

—. 1959. "Introducción a Su hombre de confianza." Buenos Aires: Emecé Editores.

PATEA, Viorica. 2011. La tierra baldía. Madrid: Cátedra.

Rodríguez, Claudio. 2004. "Anotaciones sobre el ritmo en Rimbaud". In Yubero 2004, 77-92.

Smith, Carol. 1963. T. S. Eliot's Dramatic Theory and Practice. Princeton, N.J.: Princeton Legacy Library.

—. "Eliot's 'Divine' Comedies: The Cocktail Party, The Confidential Clerk, and the Elder Statesman." In Chinitz 2014, 251-262.

Spears Brooker, Jewel ed. 2004. T. S. Eliot: The Contemporary Reviews. Cambridge UP. https://doi.org/10.1017/CBO9780511485466

TAnner, R.G. 1970. "The Dramas of T. S. Eliot and their Greek Models". Greece and Rome 2 (17): 123-134. https://doi.org/10.1017/S0017383500017782

TORRE, Esteban. 1999. El ritmo del verso: Estudios sobre el cómputo silábico y la distribución acentual, a la luz de la métrica comparada, en el verso español moderno. Universidad de Murcia, EDITUM.

Utrera Torremocha, María Victoria. 2003. "Ritmo y sintaxis en el verso libre". Rhythmica I (1): 303-333.

Yubero, Fernando, ed. 2004. La otra palabra: Escritos en prosa. Barcelona: Tusquets.

WindLE, Kevin. 2012. "The Translation of Drama”. In Malmkjaer and Windle 2012, 113-122. https://doi.org/10.1093/oxfordhb/9780199239306.013.0012

Wyman, Linda. 1991. "Where the Words are Valid: The Language of T. S. Eliot's Drama". Yeats Eliot Review 11 (2): 44-45. 